Commentary

\title{
Down to Earth: Planetary Health and Biophilosophy in the Symbiocene Epoch
}

\author{
Susan L. Prescott ${ }^{1,2, *}$ and Alan C. Logan ${ }^{2}$ \\ 1 School of Medicine, University of Western Australia, PO Box D184, Princess Margaret Hospital, Perth, \\ WA 6001, Australia \\ 2 in-FLAME Global Network, Research Group of the Worldwide Universities Network (WUN), 6010 Park Ave, \\ Suite \#4081, West New York, NJ 07093-9992, USA; aclnd@cfs-fm.org \\ * Correspondence: susan.prescott@uwa.edu.au
}

Received: 2 August 2017; Accepted: 12 August 2017; Published: 15 August 2017

\begin{abstract}
Advances in science have illuminated the role of the "ecological theatre"-the total living environment-in human health. In a rapidly changing epoch known as the anthropocene, microbiome science is identifying functional connections between all life, both seen and unseen. Rather than an easily identifiable era appearing in rock strata, the anthropocene is more of a diagnostic syndrome, a set of signs and symptoms including climate change, gross biodiversity losses, environmental degradation, and an epidemic of non-communicable diseases. The syndrome is intertwined with politics, economics, public policies (or lack thereof), social values, and a global push of calorie-dense, nutrient-poor foods and beverages. The healing of anthropocene syndrome is the grand challenge of humanity. Expanding on the "Mars Can Wait" argument of Geoffrey Goodman, et al., we focus on the urgency with which health promotion must be prioritized here on Earth. We revive Jonas Salk's biophilosophy: a call to action for collaboration between biologists, humanists, and scholars of all stripes. From this perspective, lines of distinction between personal, public, and planetary health are removed. We also describe the symbiocene: the possibility of a new epoch in which mutualism will be considered imperative. If society asks the right questions, a transition to the symbiocene is possible; the "stratigraphical" mark of the new epoch will be found in a repudiation of authoritarianism, and the promotion of empathy, cultural competency, emotional intelligence, and commitment to optimism, tolerance, and the facilitation of the WHO definition of health, i.e., the fulfillment of human potential.
\end{abstract}

Keywords: anthropocene; societies; social justice; ecology; microbiome; prevention; health policy; equity; holistic; non-communicable diseases (NCDs); lifestyle medicine

\section{Introduction}

\subsection{Scales of Health Promotion}

"Ideas determine the nature, characteristics, and behavior of a metabiological cell -an individual —or the metabiological organism, the society ... the time has arrived in which we have to realize that we are all parts of a single organism and develop some new kinds of responses and relationships".

-Jonas E. Salk, 1983 [1]

Over the last century, public health and clinical medicine have enjoyed tremendous success in their efforts toward the eradication of infectious diseases and the reduction of early life mortality. The advent of public health standards for hygiene, targeted vaccines, and clinically effective antimicrobials revolutionized societal health in the 20th century. However, multifactorial, lifestyle-driven non-communicable diseases (NCDs) are responsible for 38 million deaths annually [2]. The non-communicable variants of disease are proving to be largely unresponsive to single-agent cures and/or biotechnical preventatives. 
Beyond diagnosable diseases per se, research shows that large groups within westernized society are living with dis-ease; while not meeting specific disease criteria, individuals with so-called subthreshold (or subsyndromal) NCDs are suffering. Subthreshold depression, for example, is associated with low-grade inflammation and places an individual on a trajectory towards other NCDs. In many ways, NCDs are epidemics of co-morbidity: cardiovascular disease, type 2 diabetes, and osteoarthritis, for example, are associated with an increased risk of depression. On the other hand, depression is a risk factor for subsequent cardiovascular disease and other NCDs [3].

Pulling the lens further out, it is important to note that health promotion is not exclusively a mission toward containing disease; the World Health Organization emphasizes that health is the fulfillment of human potential, not simply the absence of disease [4]. Allowing each individual the equitable opportunity to flourish and thrive-living to one's fullest potential—defines the ultimate aim of health promotion. The Public Health Agency of Canada provides an elegant description of mental health: "It is a positive sense of emotional and spiritual well-being that respects the importance of culture, equity, social justice, interconnections, and personal dignity" [5]. Furthermore, the WHO states a truism echoed by all major mental health organizations: "There is no health without mental health".

Research under the developmental origins of health and disease $(\mathrm{DOHaD})$ rubric clearly shows that detrimental early life experiences (e.g., exposure to stress, lack of proper nutrition, and toxins) can manifest in biological dysfunctions later in life. Parental depression, for example, is associated with multiple health risks in offspring [6]. Moreover, volumes of animal studies demonstrate multi-generational effects of parental lifestyle behaviors and environmental exposures on offspring health. In other words, discourse on health promotion today is also influencing the fulfillment of human potential among future generations [7].

Finally, we underscore that the crisis of NCDs and "dis-ease" does not sit in isolation from other global concerns; rather, it is intertwined with growing socioeconomic disparities, disconnection from the natural environment, climate change, biodiversity losses, and environmental degradation $[8,9]$. It is becoming increasingly clear that health at all levels-person, place, and planet—is interdependent. Moreover, emerging research shows that human health and disease should be viewed from a holistic perspective, one in which two nested layers of biodiversity—unseen micro-organisms residing on/in surfaces with our bodies and the larger one surrounding us in the environments we call home-are intertwined. Cross-talk between microbes and the human system demonstrates a bidirectional environment-microbiota-health axis [10].

\subsection{Roadmap to the Current Review}

Here, we explore and expand upon the ideas and perspectives of polio-vaccine developer Jonas E. Salk in the context of society's responsibility to promote health across scales and over time. Although best known for a vaccine that transformed health, Salk urged society to prioritize mental health and to visualize the healthy immune system as a metaphor for societal harmony [1]. To add a contemporary perspective to Salk's lesser-known work, we first provide a brief examination of the cultural epoch known as the anthropocene; we describe the ways in which this is a "syndrome", one that needs to be healed. We argue that total health—the fulfillment of human potential—cannot take place in the anthropocene. It is our contention that such fulfillment requires a transition to a new epoch, the symbiocene.

At the height of the race to the moon, Salk, and his contemporary, the renowned microbiologist Rene J. Dubos, attempted to provoke questions concerning where society should place its financial investments in science and technology. We revive these discussions in the context of the policies that drive populist ideas of developing Mars colonies and fantastical escapes from the problems of the anthropocene. Next, we briefly review Salk's concept of biophilosophy-the investigation of biological phenomenon with input from academic disciplines that study human culture, tradition, arts, and ethics-and describe why such an approach may be essential in 21st century healthcare. 
With this background in place, we examine the emerging microbiome science as a way to illustrate symbiotic relationships and the ways in which societal "exposures"-its policies and systems-might promote or detract from health. The microbiome is a topic that has united researchers from virtually every branch of science and medicine. The ways in which the microbiome extends into health discussions ranging from the future of agriculture, to the pathophysiology of schizophrenia, have forced difficult questions upon society as a whole. All life-including the unseen-is interconnected; the "ecosystems" in our social structures, governments, corporations, and others can influence the ecosystems that sustain us, or act as barriers to health. As we discuss, in general, the emerging microbiome science has demonstrated that our lifestyle (biosis: way of living) is at odds with maintaining a microbial diversity that might otherwise help us work toward the fulfillment of potential.

Finally, we discuss Salk's biophilosophy in the context of society's responsibility to support each person's fundamental rights to achieve their potential. We refer to this as equity of the ecosystem, and underscore that personal, public, and total-species health are linked together in the shared biosphere. In the symbiocene-described as a new epoch of planetary health-priorities and perspectives shift, society remains vigilant of upstream blockages of health (rather than the downstream suppression of symptoms), and optimism prevails.

\subsection{Anthropocene Syndrome}

Culturally, the anthropocene is generally recognized to be an era in which human activity has grossly disturbed the natural environment. Human activities (e.g., energy consumption, water use, urbanization, and land transformation leading to the degradation of natural environments) in the anthropocene have brought about dire consequences, including alarming increases in greenhouse gas levels, climate change, ocean acidification, deforestation, human-manufactured toxins in air/water/land, encroachment by invasive species, and biodiversity losses. Although the origins of the anthropocene can be traced to our ancient ancestors (paleo-pollution through intentional combustion has been documented at Neanderthal sites [11]), picking up pace during the industrial revolution, for many scientists its true commencement is mid-20th century, a point at which the aforementioned environmental changes began rapid acceleration [12]. However, the term anthropocene is not under the exclusive purview of the profession of geology (although the International Commission on Stratigraphy (ICS) is currently considering an adoption of the term anthropocene, in geologic time, we remain in the 11,700 year-old Holocene [13]); rather, it serves as a multi-disciplinary descriptor for human-induced, total environmental change [14].

Coincident with these anthropogenic changes to the natural environment, massive increases in non-communicable diseases (NCDs), such as autoimmune conditions, allergic diseases, asthma, cancer, cardiovascular disease, neuropsychiatric disorders, and obesity, have also emerged as a product of human activities [15]. The prevalence of NCDs also rises in association with increases in energy consumption (in the form of westernized, ultra-processed dietary choices) and decreases in energy expenditure (in the form of sedentary behavior). Moreover, rapid urbanization, land use transformation in the built environment, and changes in marketing via telecommunications brings humans in close contact with the 'upstream' drivers of NCDs (e.g., ultra-processed/low-nutrient foods, fast-food, excess alcohol, tobacco, airborne particulate matter, and excess light at night) [16].

The anthropocene has also brought changes to the landscape in an agglomeration of fast-food outlets, take-away food shops, convenience stores, vending machines, and point-of-purchase stanchions that offer up calorie-dense, nutritionally-poor foods and beverages; the dietary choices within and on these structures are mostly at odds with our evolutionary experience [17]. For example, as part of the Framingham Heart study in the U.S., researchers have been examining the food environment and socioeconomic variables in four distinct geographic areas for nearly 40 years; today, the landscape for the average participant features about 5 times greater fast-food outlets in proximity to their home and work [18]. In a recent study of U.S. veterans, only $40 \%$ had a park within a mile of their residence, but all veterans did have an average of eight fast-food outlets in the same radius [19]. 
The ongoing proliferation of westernized fast-food outlets in Asia is astounding; in China, McDonald's outlets are opening at a rate of 10 per week, and Kentucky Fried Chicken has now amassed roughly the same number of stores in China (in comparison to the United States), but it did so in half the time [20].

The anthropocene is also the era of the highly-processed calorie. In Canada, daily caloric intake from highly-processed foods has more than doubled since the mid-20th century acceleration of the anthropocene. In the same time-frame, ultraprocessed (very highly refined) ready-to-heat dishes have increased by 23 -fold, while staples like unprocessed roots and tubers have declined by fivefold. In North America and Europe, the majority of food spending is directed at processed or ultraprocessed foods [21-23]. Not only can these foods directly contribute to metabolic dysfunction and NCDs, they also displace healthy sources of protein, fiber, vitamins, and minerals. Given what we know concerning the biological consequences of fast-food consumption-at least insofar as ultraprocessed, high-fat/sugar, calorie-dense-nutrient-poor foods dominate the menu-it might be appropriate to consider such outlets an invasive species of the anthropocene.

While there have been notable quests toward the abatement of intolerances, prejudices and biases (e.g., undoing discrimination-based racial, ethnic, gender, and sexual orientation), as well as attempts to reduce the stigma of mental illnesses [24], scholars would surely agree that we have miles to go. At the same time, there is also evidence of a polarization of societal viewpoints, increases in bullying, and higher levels of generalized incivility [25-27]. Global trends also show diminished perspective taking, empathic concern, and rising narcissism in recent decades [28,29]. Even fractional swings in the direction of narcissism (and away from empathy and perspective taking) could have enormous consequences if present at large scales of national populations. It could tip the scale towards anger, punishment, retaliation, and bullying, and away from prosocial behaviours that otherwise protect the herd in ways that vaccines cannot [30-32]. Levels of trust in one other, and in major institutions-political, medical, and journalistic - have declined in the United States [33]. Declines in helping behavior have also been noted, with indications that this might be a product of growing inequalities, social exclusion, and/or resistance to multiculturalism [34]. Surges in nationalism, evident in recent elections in the United States and Europe, may also be a symptom of the anthropocene syndrome; in particular, the disparities of globalization are pushing money, geyser-like, upward to a progressively smaller minority of society's most affluent [35], which, in turn, opens a window of opportunity for authoritarian, narcissistic leaders to emerge [36].

Evaluating the "psyche" of the anthropocene indicates that it is one of angst. Cultural differences make it difficult to determine if criteria-based diagnosable major depression and anxiety disorders are increasing throughout all nations; however, most global surveys demonstrate that psychological distress has increased over the last several decades [37]. Despite mixed results on disorders, higher levels of distress and its association with physical and mental complaints among adults and youth in westernized nations is unacceptably high [26,38-41]. The manifestations of distress on the immune system, and, as we will discuss shortly, the gut microbiota, can cast a long shadow on health over the life course.

Thus, rather than an easily identifiable geological strata due to glacial retreats, the anthropocene is more of a diagnostic syndrome, a set of signs and symptoms that are intertwined with politics, economics, policies (or lack thereof), and social values. The syndrome is driven by the global reach of westernization and neoliberal ideology. Neoliberalism provides an abundance of consumer choices-including the ultraprocessed foods, beverages, tobacco, etc., that act as drivers of NCDs-and at the same time provides the "freedom" of allowing the individual to be the primary holder of preventive strategies (i.e., solely responsible for lifestyle) for one's own health. Moreover, the ideology provides the commercially available remedies which one (and at the larger scale, society) might purchase in the hopes of offsetting the commercial drivers of NCDs [42-44]. 


\subsection{Mars Colonies and Intellectual Escapism}

"Today, the investment devoted to developing preventatives or cures for human disease and to maintain health from conception to the end of life is a pitifully small fraction of the cost of the material of war or the race into space".

-Jonas Salk, 1966 [45]

In a nationally syndicated newspaper piece, Salk reminded readers in 1966 that "enormous research sums are allocated by the Atomic Energy Commission, by NASA, by the Department of Defence, by the National Institutes of Health and by the National Science Foundation...now more than ever before there is a need for a reappraisal of sufficiency and of priority of allocations". His order of priority wasn't veiled. He argued that the main source of national pride should be found in the health and well-being status of all of its citizens. He challenged society to determine how such a goal could be weaved into national policy beyond traditional science funding; Salk advocated for a distinct 'Research Fund for Human Welfare', and suggested that any increases in spending directed at defence should be matched with distinct funding - dollar for dollar — to support health, education, and improvement in human wellbeing. Such an act would support research to identify ways to reduce hate, segregation, and conflict (as well as increasing altruism), but it would also send a signal of mutualism that "would remind the nation of its commitment to humanity" [45].

Salk dismissed cynical pessimism. If humans could split the atom, develop rockets, and pool untold resources for a few individuals to walk upon the moon, those same collective resources could be pooled to ensure every possible stone was turned over to maximize equal-opportunity fulfilment of total human potential: "I think that goodness and nobility are genetically inscribed, but they need to be evoked...the challenge of evoking the best in us may seem utterly forbidding but, surely, no more so than previously "impossible" challenges-heavier-than-air-flight, electricity, space travel" [46]. "We talk of immunizing children... but what about immunizing, say, against the kind of behavior that leads to drug abuse? Or immunizing that leads to (youth being) more responsible for themselves and responsible to society?" [47].

One of Salk's contemporaries, the renowned microbiologist and Pulitzer-Prize-winning author Rene Dubos, also stated in 1970: "The man of flesh and bone is not likely to remain long impressed by the fact that a few of his contemporaries can explore the moon if the planet Earth becomes unfit for his everyday life" [48]. Dubos was optimistic that the colorful image of a vibrant Earth viewed from space would galvanize a new "theology of the Earth". Like Salk, he maintained that the Apollo program was inspirational, because it "demonstrated once more that the human spirit derives boundless power from a poetical faith in what it can do. Since we learned so rapidly how to integrate the skills of scores of thousands of minds on the closely-knit space endeavor, we should be able to develop programs for the management of the ecological systems of the Earth" [49]. But in 1969, Dubos also argued that fellow scientists engaged in both intellectual escapism and intellectual dishonesty by chasing down pathways that have little bearing on the social and ecological forces impacting human health:

"The technology cannot cure the intellectual dishonesty that burdens its channels today. Even more dangerous and more universal is intellectual escapism, the attempt to escape the real problems around us ... we organize meetings about it in all sorts of pleasant places to talk about this [biomedicine], and that saves us the responsibility of walking across the street, where 100,000 children are being poisoned every day by lead in paint...something can be done immediately about this problem, but it is not being done because it is not of sufficient interest or as exciting intellectually as talking about changing the genetic nature of man" [50].

Almost half-a-decade later, we continue to have issues with lead in the childhood environment, most especially in disadvantaged communities [51]. But the point Dubos was making was not about lead paint per se. Our focus here is on the staggering costs of intellectual escapism in the form of ignoring mental health; conservatively estimated, the direct societal costs of mental health disorders in the United States and Europe (combined) are well over a trillion U.S. dollars (USD) [52]. However, 
that does not include the interactions between mental illness, substance abuse, and the reality that "developed" nations often use prison as their primary mental health institution [53-55]. However, even these unfathomable costs exclude the burden of subthreshold conditions and comorbidity (i.e., mental distress as an accelerator of NCDs). Consider still the transgenerational (epigenetic) effects of stress and mental illness [56], and beyond brain and behavior disorders, it is almost impossible to calculate the societal burden of small- and large-scale aggression and incivility [57-59]. In a vicious cycle, both victim and perpetrator are on a trajectory to depression, isolation, and ill-health [60-62].

Experts in public health and medicine are surprisingly quiet on discussing matters of equity in the public financing of science for the benefit of health equity. Given the aforementioned financial implications of the slogan "No Health without Mental Health", colossal as they are, Salk and Dubos appeared to be dissenters by raising the spectre of establishing differing priorities in publicly funded research. In a rare 2014 article within peer-reviewed literature, scientist Geoffrey Goodman and colleagues made a case for better funding of neuroscience and establishing priorities here on Earth:

"It is crucial that increased knowledge and understanding of brain anatomy and function, the mind and consciousness, have absolute priority if we are to find ways to ameliorate extremes of human aggression, mental sickness, and brain aging and pathologies ... claims of immediate, economic and human side benefits from space research, for jobs, inventions and curiosity, apply no less to the life sciences. Cosmic issues fade before urgent exploration of the human brain. Mars can surely wait 30-50 years" [63].

However, their attempt to raise the notion that Mars Can Wait (the title of the Goodman article) was not a very popular effort. The paper has essentially gone uncited. The Trump administration has granted the National Aeronautics and Space Administration (NASA) a U.S. $\$ 19.5$ billion budget in 2017, with the understanding that one of its goals is human exploration of Mars [64]. The 2017 NASA budget is 13 times larger than government funding provided to the National Institutes of Mental Health. In addition, the Brain Research through Advancing Innovative Neurotechnologies (BRAIN) Initiative of the National Institutes of Health, although introduced with fanfare as part of a "Grand Challenge", received \$195 million USD in 2017 to explore the inner universe of the brain [65]. For perspective, a rocket which bypassed Pluto in July 2015 cost $\$ 720$ million USD.

It is not our intent here (nor was it that of Goodman, et al. [63]) to debate the extent to which various government investments in rocket science, including crewed missions, pay dividends for society [66]. Undoubtedly, they do provide benefits in technological advances, including those which are eventually used throughout society. However, it is important to highlight what space exploration programs have not done: diminish socioeconomic inequalities, curb epidemics in NCDs, dismantle the prison-industrial complex, tackle incivility, end conflict (154 U.S. service members were killed in Vietnam during the brief 16-24 July 1969, Apollo 11 journey to the lunar surface and back [67]), and provide insight into the ways in which aggression and authoritarianism block human health. Rocket science has allowed a select group of humans to walk on the moon, but the barriers to human health and NCD reduction are proving to be far more complex than rocket science.

Thus, our discourse here is not about the finances of NASA per se, and clearly investments in Earth science data are essential. Moreover, the NASA budget is a small fraction of the nearly 600 billion USD defense budget. Rather, we question why such (publicly funded) Apollo-like "moon shot" efforts are not directed at grotesque problems here on Earth, first. Globally, spending on mental health is less than two U.S. dollars per person, per year and less than 25 cents in low income countries [68]. The costs of ignoring (or providing lip-service to) mental health cannot even be properly calculated, yet society invests so little in finding solutions to trillion-dollar problems. Even partial solutions to the problems of mental disorders and unfulfilled potential in life would pay unimaginable benefits to society.

As we argue below, the complexity of NCDs and their subthreshold variants in the anthropocene will require multidisciplinary collaboration in health promotion, and a reformation of medicine in the 
21st century. The idea of "immunization" — not only against NCDs, but for support of the fulfillment of human potential — was raised by Jonas Salk, the famed physician-scientist who helped eradicate polio. He suggested that societies would need to rally against the threat of NCDs with vigor; lessons learned from the development and application of biomedical vaccines could be extended into the total ecological context of human development with an aim toward health (as the WHO defines it) and through mutualism, bringing out the best in one another. He posited that collective actions in society could work for-or against—biological systems, most notably the immune and central nervous systems.

Deeper dives into the brain, the so-called final frontier of medical science, may provide untold benefits to society. However, the "Mars Can Wait" in favor of the brain argument runs the risk of simply deflecting society's scientific resources into a tight silo of neuroimaging and pharmaceutical development. It runs the risk of simply supplanting rocket technology with neurotechnology and maintaining the myth that the brain lives in isolation. We are learning that the encephalon is not the conductor of the orchestra as once thought; in many ways, it whistles to the tune of the immune system, which in turn acts as a mobile sensory organ, responding to the total environment and the microbes that live on and within us. The microbes and their activities, in turn, are a feature of the contemporary diet and lifestyle. As we will explain, the unseen microbes may be important players in the theatre of human health, but they, too, are a product of how we live, and a product of our societal ecosystems, not only our stressors, but our positive emotions as well.

Salk, who was a global leader in the fight against single-agent infectious disease, also had keen awareness of the limitations of pursuits in biological sciences when matters were more complex. In his words, bench laboratory work needed the context of the "laboratory of the world" [69]. In order to solve global problems, even those that might have biological solutions, Salk argued that biological scientists would need to seek counsel from scholars in the humanities, social sciences, and arts. He favored collaboration for many reasons, especially because "man's most persistent and difficult biological problem will not be his physical diseases, certainly not as in the past, but his relationship to himself and his fellow man" [70]. If for no other reason, Salk urged interdisciplinary alliances to help biologists ask the right questions in their research pursuits: "It's the questions that we need to discover, because the answers preexist. If we ask the right questions, the answers will come" [71].

\subsection{Biophilosophy}

"What might happen if biologists and other scholars so oriented were to combine talents even more than they do now, not simply to develop further their own special interests individually ... [they] ... are realizing more and more, their responsibility to society as well as to themselves".

-Jonas E. Salk, 1962 [70]

In order to maximize the odds that societal investments in biological sciences would provide systemic health benefits, Salk maintained that biologists needed to be guided by a collective of scholarly thought: a "biophilosophy" approach. While he did not coin the term biophilosophy, Salk did popularize and provide meaning to the concept. He pointed out that there was an absence of professional philosophical input into the meaning and consequences of scientific endeavors: how were choices concerning topics of research being made within the biological sciences, and how were findings matched to the priorities of society? Salk maintained that as an anthropocentric "sense of responsibility in the evolutionary scheme" [70] grows-the increasing realization of human influence over total health among all living species—careful questions could determine the roads travelled by the biological sciences.

Salk referred to the humanistic and cultural context of scientific query as meta-biology, and its understanding required diversity and coalition of thought from biologists, philosophers, and humanists. Without such input, research investments in biology could be oriented heavily toward findings that may (or may not) support developments of biomedicine, but do little to tackle the larger problems faced by humanity: aggression, violence, and threats to the living ecosystems which sustain life. While strictly 
applied science developed the polio vaccine, it couldn't always be forced to fit—Rosetta Stone-like-into the ecological complexities of NCDs and human healing. Moreover, massive public investments in the sciences were often being made without human welfare in mind.

To be clear, Salk was a proponent of basic science as the entry ramp to biological discoveries, including those directed at mental health. In particular, he was interested in the relationships between the immune system and the central nervous system. In 1962, he argued that increased biological knowledge can spawn new ideas that, through collective thought, can help not only with "physical diseases but diseases of unreasonableness, prejudice and selfishness" [72]. Salk never wavered from the important role of reductionist scientific query: "if in time we could understand the relationship between immunology and brain mechanisms...then we would have some very powerful tools against disease" [73].

From the perspective of biophilosophy, we can highlight the importance of functional ecosystems ("eco" from Greek roots oi kos or oikos; house/dwelling place) within the anthropocene. Whether used in the narrow biological sense of the word—or in corporate, government, neighborhood, institutional, and other settings - an ecosystem is a community of living organisms operating within an abiotic setting. Biophilosophy in this context underscores that ecosystems of the houses of national governments, town halls, "Big" corporations, political parties, or Silicon Valley (to name but a few) all involve living organisms operating within non-living (in this case, built) environments. Operations within each of those and countless other anthropocentric ecosystems extend outwards and impact the health and disease of all species with near and distant ecosystems. Erased are the "fences" dividing a person's residence, their neighborhoods, surrounding municipal and national dwellings (which house the houses), and outward to our large, universally shared ecosystem, the $n=1 \mathrm{dwelling}$ place of Earth. The illumination of this interconnected web of life-i.e., connections between human lifestyle and the health of all planetary species, including humans-has been sourced from the most unlikely place. That is, the previously unseen and underappreciated role of microbes.

Before discussing the emerging research on microbes and its connection to biophilosophy, a brief biological colloquy on allostatic load, epigenetics, and low-grade inflammation seems necessary. In response to chronic stress, sustained elevations in stress hormones and/or inflammatory immune chemicals lead to wear-and-tear, or cellular damage of physiological dysregulation. These are intertwined with further anxiety, stress, and depression (which compounds the problem); this chronic state of persistent physiological activation is called allostatic load, and its detrimental cellular effects, allostatic overload [74]. The mechanisms through which allostatic load can impair health include epigenetic modifications (e.g., methylation of the CpG dinucleotide in DNA, acetylation and methylation of histones, and the binding of small non-coding RNAs to DNA) that can activate or silence specific genes. Such modifications, reinforced through studies involving identical twins, also help to explain how total environmental exposures over the life course-lifestyle, environmental toxins, socioeconomic disparities, access to nature, aspects of the built environment, etc.- differentially impact the health risk of individuals throughout society [75].

Central to all discussions on health and disease, including allostatic load and epigenetics, is the immune system. In many ways, the immune system is the primary interface with the external environment, and many of its cells are part of a mobile mind, recording events into memory and providing critical information to the brain. Chronic, low-grade inflammation (distinct from acute, life-saving inflammatory responses) has been linked to socioeconomic disadvantage, environmental insults (including the aforementioned lifestyle habits of the westernized diet), excess alcohol, tobacco use, sedentary behavior, exposure to toxins, and psychological stress. Persistent depression and anxiety can predict low-grade inflammation $[76,77]$. On the other hand, low-grade inflammation (demonstrated most notably by laboratory-induced elevations in inflammatory cytokines, such as IL-6 and TNF- $\alpha$ ) can itself promote depressive symptoms, anxiety, fatigue, cognitive disruptions, and pain [78]. Moreover, chronic inflammation is associated with epigenetic changes [79], and appears to contribute to most, if not all, NCDs [80]. 
The bidirectional relationships between low-grade inflammation and mood disturbances are also found between inflammation and alterations to human-associated microbes [81,82]. As we segue to discussions of the emerging science of microbes, we underscore at the outset that they are intimately connected to the aforementioned biological mechanisms of chronic disease: allostatic load, epigenetics, and immune functioning. Furthermore, microbes influence these biological mechanisms at the intersection of food systems, marketing, time spent in biodiverse natural environments, education, income, prejudice, and other social determinants of health and disease.

\subsection{Microbiome: Metaphor for a Broken System}

To appreciate how the scientific revolution in microbiology has transformed what it means to be human, we now know that approximately $50 \%$ of our cells are bacterial [83], and more than $95 \%$ of our genes are microbial [84]. The term microbiome refers to microbes and their collective functional genomes operating within an ecological niche [85]. Microbiome science has illuminated the value of mutualism in sustaining life. In humans, the beneficence of microbes includes protection against pathogens, enhanced nutrient absorption, maintaining gut/skin and other barriers to the outside environment, reducing the burden of potentially harmful environmental chemicals (xenobiotics), and the manufacture of various chemicals-e.g., short chain fatty acids and transformed phytochemcials-which support survival. In addition, and of vital importance to the present discourse, microbes "educate" the immune system in early life; that is, interactions between microbes and the immune system prepare for appropriate responses to an ever-changing physical and mental environment.

At this stage, researchers are unclear on what an "ideal" healthy gut microbiome might be, although it is becoming increasingly clear that losses of microbial diversity are yet another feature of anthropocene syndrome. Research from the ever-diminishing groups of people living life in traditional ways-with closer resemblance to our human ancestors (hunter-gatherer, early subsistence) and insulation from westernized diet and lifestyle influences-shows general losses in microbial diversity along the scale of westernization and industrialization [86,87]. The loss of microbial diversity as a result of westernized dietary practices, with its fiber and phytochemical-deficient foods, may even extend over generations [88]. A loss of diversity generally equates to a loss of functional benefit and threat to a healthy ecosystem.

Dysbiosis translates from its Greek root as "life in distress". While dysbiosis is an apt term for anthropocene syndrome, in the microbial context it means disruptions to the structure of complex commensal microbial communities, involving one or more of the following: the loss of beneficial micro-organisms, and/or the expansion of potentially harmful microbes, and/or the loss of overall microbial diversity [89]. When researchers induce dysbiosis in animal studies-typically by antibiotic administration, provocation of stress, or a high-sugar/high-fat westernized diet- the fallout includes behavioral changes (indicative of depression and anxiety), metabolic disturbances (reflecting human obesity and type II diabetes), body-wide low-grade inflammation, and oxidative stress [90].

The cumulative exposures which may erode the diversity of the human microbiome in westernized nations-and its link to a higher burden of NCDs in socioeconomically disadvantaged individuals and communities-has been described as the "dysbiotic drift" hypothesis [91]. The dysbiotic drift theory pulls the lens back from single exposures; when examining the risk factors for dysbiosis it becomes fairly clear that these are the very same factors related to the total lived experience in socioeconomic status (SES) disadvantage. Psychological stress, westernized diet (i.e., with its missing nutrients, added chemicals, and advanced glycation end-products) consumption, circadian disruptions, excess alcohol and tobacco use, phthalate and environmental chemical exposure, and higher antibiotic prescriptions are not randomly distributed. These factors of the exposome press upon the microbiome along SES lines $[3,91]$. Indeed, mucosal biopsy samples (one of the more accurate ways to sample the intestinal microbiome) demonstrate the reduced diversity of the intestinal microbiome among residents of lower SES neighborhoods in North America. 
Again, Salk used the immune system as a metaphor for societal actions, over-reacting in certain situations, and suppressing in others: "I think that mankind is suffering from a lot of symbolic autoimmune disease, as well as from some symbolic cancers" [1]. Dysbiotic drift appears to be yet another literal and metaphorical marker of anthropocene syndrome; from the biomedical and neoliberal perspective, the overlap between the factors of dysbiosis (in its actual "life in distress" translation and/or the microbial translation) and SES disadvantage is remedied by biotechnical solutions and personal choices in healthy eating, exercise, and stress management. While it is reasonable to expect societal members to engage in health-promoting actions and take personal responsibility for many aspects of NCD-prevention, the neoliberal marketing forces which drive dysbiosis are underappreciated, and potent.

\subsection{Dysbiosis and the Mental Environment}

Although much has been written on SES disadvantage in mainstream academic writing, it is often cited with detachment, jargon, and fragmented measures which can obscure the ability to understand the sum of the total lived experience [92]. Research on allostatic load informs us that past experiences in the ecological theatre would prime the individual for higher levels of inflammation and oxidative stress in response to stress. Consider that even the mere researcher-invoked feeling of poverty or belonging to an SES "out-group" (in a laboratory setting) is enough to alter dietary choices in the direction of low-nutrient, high-calorie foods [93-95].

Now we can turn toward the visualized environment, one which has been described by our research group as "grey space" $[3,91]$. This refers to an area with a disproportionate number of bars, liquor stores, convenience stores, fast-food outlets, and tobacco vendors. Beyond the physical structures enhancing availability-over $30 \%$ of the variance in excessive fast-food consumption may be attributable to a clustering of fast-food outlets [96] — billboards, sidewalk signage, and ads in public transportation systems cajole toward dysbiotic choices [97]. Most likely as a product of marketing and availability, children in lower SES neighbourhoods can more readily identify the logos of multinational fast-food outlets [98]. On the other hand, the availability of healthy dietary choices may be subpar, more expensive, or shelved in such a way as to be subordinate to energy-dense, low nutrient foods [99-103]. Such research demonstrates that the connections between socioeconomic inequalities, fast-food, and NCDs [104,105] (and it its most extreme end, mortality [106]) are not on a level playing field.

In other words, the global marketing of fast food, soft drinks, ultraprocessed foods, tobacco, alcohol—all of which have been shown to have a detrimental effect on gut microbiota in humans or experimental animals—cajoles, or manipulates, society toward many lifestyle choices. In essence, the fast-food jingle on the radio, should it get a return on investment by influencing the vehicle operator to turn into the drive-through for a dinner filled with high-fat, high-sugar, and low-nutrient dietary items, is a manipulator of the microbiome. Thus, biomedicine is attempting to undo dysbiosis ("life in distress") by manufacturing drug-oriented solutions for the problem of microbial dysbiosis; at the same time, the problem of dysbiosis in its actual definition (life in distress) and microbial sense (loss of beneficial microbes) is being manufactured, at least in part, by a system in which the multinational marketing of dysbiotic products is left unchecked. As stated succinctly in The Lancet (in 2013), one of the world's leading science/medicine journals, profits in the food, alcohol, and tobacco industries encourage pandemics of NCDs [107]. We consider it fascinating that previously unseen members of the Earth's biodiversity-microbes-are allowing humans to see very clearly how such NCD-provoking systems are interconnected, and why they press upon the most vulnerable in society.

As we argue here, the promotion of health as the World Health Organization defines it-that is, the fulfillment of human potential, not simply the absence of disease-requires a dramatically different approach. Personalized medicine, in our view, can only fulfill its full potential if each individual is empathically understood from the perspective of their total lived experience. The health of human bodily systems is a product of total environmental health; total environmental health is predicated on societal choices and the prioritization of human activities, which are geared toward promoting 
ecosystem health at all levels: micro, meso, and macro. Thus, there are no sharp lines separating personal health from healthy ecosystems at all levels. The health of ecosystems at the level of the household, neighborhood, state/province, nation, and outward to the $n=1$ planet are all inter-related. A universal understanding of this perspective can be the demarcation line which signifies the beginning of the end of the anthropocene, and, as described below, the hope for a new epoch, the symbiocene.

\subsection{The Symbiocene}

"The Symbiocene will be that period in the Earth's history where humans symbiotically reintegrate themselves, psychologically and technologically, into nature and natural systems".

—Glenn Albrecht, 2014 [108]

Biomedicine is moving rapidly in the direction of large-scale measurements and analyses of functional proteins (proteomics), metabolites (metabolomics), gene expression (epigenomics and transcriptomics), and genetic influences on drug/isolated nutrient metabolism (pharmacogenomics). It is hoped that these and other molecular "omics" techniques will help to develop personalized or precision medicine (i.e., the right drug or treatment plan at the right dose, given to the right patient at the optimal time), perhaps paying off handsomely for individuals and society [109]. But the biophilosophist will ask how, precisely, precision medicine will be delivered? Is it destined for the affluent, is it motivated by profit alone, and to what extent is it oversold? Nonetheless, the very need for precision medicine directed at NCDs will still be determined by the "causes of the causes" (i.e., an individual consumes a diet which causes cardiovascular disease (CVD), but what causes the person (or societies at large) to consume such diets?). Personalized medicine, in our view, can only fulfill its full potential if each individual is empathically understood from the perspective of their total lived experience.

Recent studies have shown that biodiversity losses are far more significant than previously realized. Indeed, the current state of disappearing flora and fauna species, rapid as it is, has been described as "biological annihilation" [110]. The emerging microbiome science has helped to highlight the concept of symbiosis (Greek: syn/m = together; way of living together), and to describe the ways in which it might apply to healing the comorbidity of NCDs, environmental degradation, biodiversity losses, and climate change. The idea of a new epoch of mutualism (both biological and social) originates in the writings of Jonas Salk. He referred to the first 10,000+ years of human existence as Epoch " $\mathrm{A}$ ", wherein life and lifestyle was a response to infectious diseases and other causes of early mortality. The new Epoch "B" would be-through evolution of thought and the necessity of solving self-induced global problems-one in which humans will value "collaboration and interdependence ... change the way we relate to each other and enter into a kind of relationship which I call mutualism, or mutual cooperation. What I'm thinking of is an ecosystem dominated by mutually advantageous relationships rather than mutually destructive relationships ... eventually we'll realize that if we destroy the ecosystem, we destroy ourselves" [111]. Elaborating on the fulfillment of potential in the new epoch, Salk stated: "We need to address ourselves to questions such as meaning and fulfillment, satisfaction. And I'm not talking about satisfaction of myself as an individual without respect to all others. I'm thinking of the notion of mutualism...recognizing that my fulfillment helps in your fulfillment, your fulfillment comes in my fulfillment and we are all part of humankind together" [112].

Salk also maintained that the practice of medicine itself would be transformed in the new epoch. In 1977, he said "we are entering into a new Epoch in which holistic medicine will be the dominant model", and he distinguished holistic health from medicine. Medicine, he said, "refers to the repair of ailing parts, but health is the properly functioning whole" [113]. Such a view was in keeping with the perspective of biophilosophy as a guide for biological studies; discussions of the health of the brain, gastrointestinal tract, immune system, and all bodily systems would become less compartmentalized and, increasingly, one-in-the-same. So, too, Salk maintained that the body should be considered part of the properly functioning whole of the external environments: its biodiversity, its social policies, and its practices: "We must see ourselves as part of the ecosystem. Where we were once a product of evolution, we are now part of the process" [114]. 
More recently, philosopher Glen Albrecht has expanded these notions of global mutualism and has described the post-anthropecene in optimistic terms, coining the term symbiocene. Although there are predators and pathogens in nature, and certainly competition, so too are there boundless examples of macro and microscale mutually beneficial relationships between organisms. Albrecht argues that we can apply the lessons from the natural world and direct those towards broken systems (political and otherwise), such that we replicate the symbiotic and mutually reinforcing operations of life-sustaining processes found in living systems $[108,115]$.

The microbiome provides a bounty of scientific research throughout the natural world demonstrating the mutual benefits of microbes and host. In addition to the aforementioned human microbiome research, volumes of international research are highlighting the ways in which microbes can enhance plant vigor, increase drought resistance, and protect against pathogens. Remarkably, researchers have shown that exposing small seedlings to the microbiome-rich leaf litter derived from adults (of the same plant species) protects them and increases their chances of thriving [116].

From our perspective, the ability to apply lessons from nature is predicated upon a greater understanding of and connection to the natural world. This will require strong educational efforts, especially early in life, as we try to curb the contemporary disconnect from nature; that is, we need to prevent what researchers have termed the "extinction of human experience" in natural environments [117]. Moreover, a prerequisite to mutualism in symbiotic societies is cultural competency; this requires an understanding that individual human life and lifestyle cannot be separated from the attitudes, values, and mores that are associated with different groups within societies. Cultural competency is described as a set of consistent behaviors, attitudes, and policies that enable a system, agency, or individual to work within a cross-cultural context or situation effectively [118]. Thoughts and actions—global outlooks and lifestyle—can differ along racial, ethnic, social, economic, geographic, and/or linguistic attributes or identities.

Collectively, such a diversity of thoughts and ideas can be an asset to the promotion of health and quality of life in organizations, institutions, and multicultural society. An absence of diversity in thought, especially in sciences directed at societal health, runs the risk of bias in benefit $[119,120]$. Biophilosophers-diverse thinkers asking "who's science and toward what aims?"—can help to harness the rich potentiality of scientific developments, directing societal energies and resources toward the appropriate destinations for symbiotic social and planetary benefit.

The symbiocene envisioned by Salk and Albrecht is not simply an era where we swap out fossil fuels for sustainable power sources; it is an era in which we fulfill the fundamental aspects of the many public health Charters. They are easy to write, as Dubos said, at meetings "in all sorts of pleasant places". So, too, is it easy to speak of "mental health", supporting the troops, and the adventures of "Mars" colonies while a veteran's homeless shelter loses public funding [121] and twenty veterans commit suicide every day [122]. Fulfillment defines the symbiocene's commitment to equitable access to healthy, nutritious food and 'stable, sustainable, and healthy ecosystems' as stated in the recent Vienna Declaration on Public Health [123]. Many are the Charters that maintain humans have a fundamental right to live in an environment that supports overall health and well-being [124]. Further, the United Nations states that children have the right to be supported in the development of "talents and mental and physical abilities to their fullest potential (and development of) respect for the natural environment" [125]. Given the established connections between the measurable psychological construct of nature relatedness (affinity to the natural world) and numerous aspects of physical and emotional well-being (as well as proenvironmental behavior and empathy) [126-129], and relationships between the childhood self-exploration of natural environments to adulthood environmental citizenship and connections to the natural world [130] (that is, the world of biodiversity which sustains human life), the new era of the symbiocene is not back to nature, but rather forward with nature.

Science can help guide the way toward the symbiocene, and in particular, begin to examine the ways in which total environmental exposures can also promote resiliency and health. For decades, scientists focused almost exclusively on disease states, depression, anxiety, stress, and detrimental 
exposures (toxins, heavy metals, particulate matter, etc.), while largely ignoring how positive or beneficial exposures help to shape the healthy individuals we call "resilient". Interest in the "exposome" (total exposures and their impact on genes over time) has shifted toward these beneficial exposures: natural environments (e.g., green space), beneficial microbes, and psychological assets (e.g., optimism, sense of wonder, openness to experience, and emotional intelligence) [3,75].

Empathy and mutualism is good for society at large. For example, empathy is associated with life satisfaction, overall well-being, rich social networks, healthy relationships and workplace performance, accommodative behavior, and prosocial activity [3]. However, as Salk maintained, this needs to be taught by example at a young age; longitudinal research shows that higher levels of early life empathy predict social competencies [131].

Emotional intelligence (EI) is, collectively, yet another societal asset. It includes the ability to discriminate between negative and positive emotions; by contemplating emotions, recognizing them in the self and others, and managing thoughts and actions, a more effective path to problem solving can be realized. EI has been associated with physical health and well-being [132-134]. Positive affect is a mediator of high EI and life satisfaction [135], and in adolescents, high EI is associated with happiness and resiliency against depression [136]. In line with other positive emotion/positive emotional attributes, there are interconnections with a healthy lifestyle. On the other hand, factors such as sleep deprivation can decrease EI [137].

The effects of EI can be far reaching. Younger children high in EI are more likely to be prosocial and less likely to engage in bullying behavior [138]. Higher EI can predict subsequent academic success [139], and, remarkably, higher EI in math educators has been linked with greater achievement among their young students [140]. Maternal EI has been shown to be predictive of offspring EI and adaptive behavior in children under stressful conditions [141,142]. Encouragingly, EI is malleable and programs geared toward EI can improve mental health, well-being, and empathy [143-145].

In sum, the symbiocene represents an era where education and awareness of the benefits of empathic and emotionally intelligent citizens, institutions, and systems will be prioritized for societal good. The driver of this process will be biophilic science. Such a science describes investigations with an aim toward the promotion of life, human, and total species welfare in mind. Biophilic science understands that allostatic load, dysbiosis, mental distress, microbiome diversity, living wages, and environmental toxin exposure do not occur equally throughout society; it also understands that positive psychological assets are not on a level SES playing field. Biophilic science is not content with determining that a Mediterranean diet is good for health and the growth of our beneficial gut microbes; it asks why there is not equal access to such a diet [146]. Biophilic science in the symbiocene seeks to develop ways to curb health-corrosive exposures and identify assets of resilience, while at the same time prioritizing its activities toward those with the greatest need.

\section{Conclusions}

Global society is staring down formidable challenges to health at all scales: person, public, and planetary. The available evidence suggests that the physical environment has been structurally and functionally altered in a rapid and dramatic way over the last half century. Indeed, the level of evidence of gross environmental change has satisfied the Anthropocene Working Group such that this team of scientists has encouraged the ICS to officially announce the anthopocene epoch [13]. We consider this an important step, if only so that scientists and the society they represent can get on with supporting a global vis medicatrix naturae. Still, "anthropogenic" does not have to be a pejorative term. As Dubos pointed out in Science (1976), humans have also engaged in creative transformations of natural environments over millennia, and that such wisdom, if used properly, can facilitate imaginative changes to the environment that could be of mutualistic benefit to humans and planetary life [147]. The symbiocene represents a new epoch in which greater emphasis is placed upon mutualism (see Figure 1). 


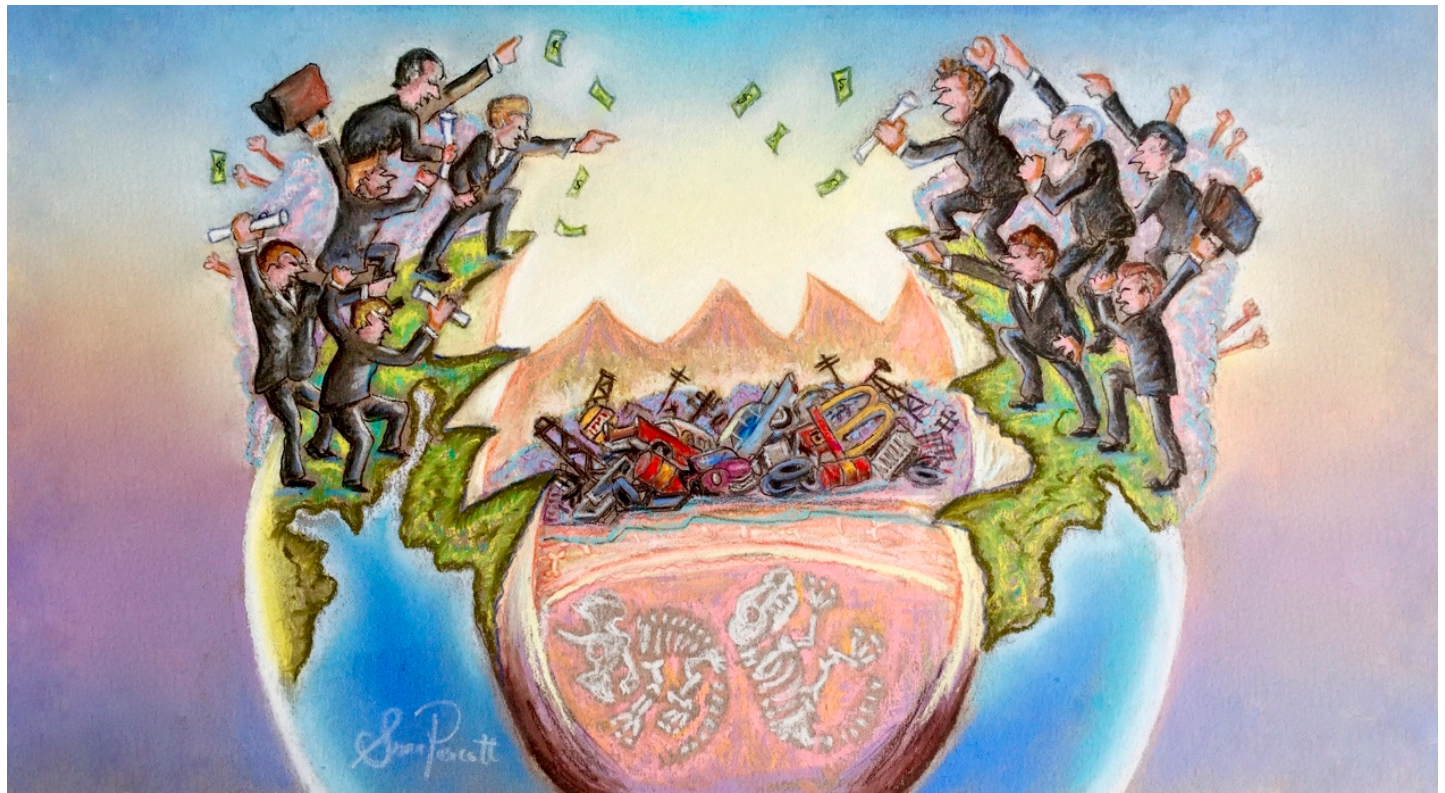

Figure 1. Anthropocene Syndrome: a complex of environmental degradation, biological annihilation in the form of species losses, non-communicable disease epidemics, climate change, and increasing incivility in public and professional discourse. The symbiocene can transcend these trends. The health of people, place, and planet requires compassion, education by example, civility, and diversity of thought. Image with permission: Susan L. Prescott.

At the same time, exiting the anthropocene will require greater vigilance toward the upstream barriers to health, and to the reality that NCDs are a societal threat. Obesity isn't "just" greater adipose tissue storage and metabolic dysregulations. It is a person who gets bypassed for a job because of biases and stigma. Maternal depression isn't "just" lowered mood. It is a life threatening illness; both maternal and paternal depression can also profoundly impact the life of offspring. The pathways linking early life exposure to later health and disease are complex; to illustrate this, maternal antenatal depression increases the likelihood that offspring are subjected to bullying by childhood peers over a decade later [148].

Thus, society must visualize future consequences today. Salk maintained that in the new epoch, living humans would begin to prioritize their role as future ancestors. That is, an epoch in which, collectively, societies will want "those who follow us to look back on us as having been wise ancestors, good ancestors" [69]. There is a moral imperative to protect the herd. Vigor and passion toward that goal is clearly visible in efforts to tackle infectious disease (e.g., vaccine campaigns), but it seems to fizzle when herd protection involves the non-communicable variant of disease, clouded by neoliberalism and consumer choice. It is past time to take on anthropocene syndrome with the same vitality and disdain as if it were a large-scale tobacco ad campaign aimed at kids.

In 2015, the Rockefeller Foundation-Lancet Commission on Planetary Health concluded that health promotion needs to be viewed through a new, holistic lens: "the achievement of the highest attainable standard of health, wellbeing, and equity worldwide through judicious attention to the human systems-political, economic, and social - that shape the future of humanity and the Earth's natural systems that define the safe environmental limits within which humanity can flourish" [8,9]. This transition from public to planetary health is a professional acknowledgement that public health (the historical vanguard for social justice) cannot be restricted in its reach [149]; achieving the goals of public health is predicated on ecological justice and the stability of fragile planetary ecosystems that sustain all life [3]. The emergence of "Planetary Health" as a collective vision for science, medicine, and all of society is a compass pointing toward the symbiocene. 
However, from our perspective, the effort to magnify the importance of global ecosystems in human health will only be as successful as our ability to undo intellectual escapism and prioritize the Earthly problems which NASA is ill-equipped to fix. On announcing the nearly $\$ 20$ billion NASA budget for 2017, President Donald J. Trump stated "American footprints on distant worlds are not too big a dream" [66]. We ask, is it too big a dream to cure anthropocene syndrome, first? We ask, rather than worrying about the mental health and neurotransmitter levels of those traveling to Mars [150], or the ways in which an unplanned pregnancy during an interplanetary mission "could put the entire crew in danger" [151], could we use this valuable time here on Earth to research the kind of life we would want on Mars? What is the endgame here? Is it to transplant the same way of life-biosis - that necessitates even the mere idea that humans should start colonizing Mars? Amid the talk of "terraforming" or seeding Mars with microbiological life and creating a Martian biosphere, should there be some discourse on how to seed human empathy, equity, emotional intelligence, accommodative (non-aggressive) behavior, mutualism, and compassion within that fantastical biosphere? The lab to research and plan for the dream life on Mars is here, right now, on the Earthly plane. We maintain that there is nothing extravagant or utopian about aspiring to turn over every scientific stone possible if the endgame is in the interest of health equity here on Earth.

Jonas Salk may be best remembered for helping to develop a highly effective vaccine to stop polio, but that is not what he wanted to be remembered for; in 1980, he stated that posterity might recognize him more for developing a unique model of biophilosophy in his institute. Only time will tell. Salk expressed disappointment that his vision was not adopted by the personnel around him, noting that academics and training in science was set up to reward the highly specialized, and not the integrators: "The institute has not gone in the direction of integrating scientific knowledge with philosophical and humanistic questions... we must do something to place a value on those able to integrate large realms, to organize complexity, as does nature. The human future depends on it" [152]. However, at the close of his life, he still maintained that "the idea was ahead of its time" [153]. For now, we close on his words, and emphasize that they seem more urgent now 40 years on. His vision for the Salk Institute might be a template for the global institution of planetary health in the symbiocene:

"The creation of the institute is more important and more significant. Here, we are working for the excellence of human health. Individual subject matters are studied for their relevance to the problems of humankind from the scientific and philosophical points of view. Hopefully, this institute will choose the more important problems to address. We are laying the foundation to understand more about ourselves and nature" [154].

Author Contributions: Susan L. Prescott and Alan C. Logan made substantial contributions to this invited opinion article; this included the acquisition, analysis, and interpretation of data. Susan L. Prescott and Alan C. Logan made equal contributions to the drafting of the manuscript and its intellectual content. Susan L. Prescott and Alan C. Logan agree to its total content.

Conflicts of Interest: Susan L. Prescott reports the following: Scientific Advisory Board and speakers fees from Danone Nutricia, Schiphol, The Netherlands and Nestlé Nutrition Institute, Lausanne, Switzerland; consultancy fees from Bayer Inc., Whippany, NJ, USA; speakers fees from Health World Inc., Queensland, Australia. Alan C. Logan has received consultancy fees from Genuine Health, Toronto, Canada and speakers fees from Health World Inc., Queensland, Australia.

\section{References}

1. Stoler, P. A conversation with Jonas Salk. Psychol. Today 1983, 17, 50-56.

2. Allen, L.N.; Feigl, A.B. What's in a name? A call to reframe non-communicable diseases. Lancet Glob. Health 2017, 5, e129-e130. [CrossRef]

3. Prescott, S.L.; Logan, A.C. Transforming life: A broad view of the developmental origins of health and disease concept from an ecological justice perspective. Int. J. Environ. Res. Public Health 2016, 13, 1075. [CrossRef] [PubMed]

4. World Health Organization. Mental Health: Strengthening Our Response; WHO Fact Sheet No. 220; World Health Organization: Genava, Switzerland, 2014. 
5. Orpana, H.; Vachon, J.; Dykxhoorn, J.; McRae, L.; Jayaraman, G. Monitoring positive mental health and its determinants in Canada: The development of the positive mental health surveillance indicator framework. Health Promot. Chronic Dis. Prev. Can. 2016, 36, 1-10. [CrossRef] [PubMed]

6. Havinga, P.J.; Boschloo, L.; Bloemen, A.J.; Nauta, M.H.; de Vries, S.O.; Penninx, B.W.; Schoevers, R.A.; Hartman, C.A. Doomed for disorder? High incidence of mood and anxiety disorders in offspring of depressed and anxious patients: A prospective cohort study. J. Clin. Psychiatry 2017, 78, e8-e17. [CrossRef] [PubMed]

7. Baird, J.; Jacob, C.; Barker, M.; Fall, C.H.; Hanson, M.; Harvey, N.C.; Inskip, H.M.; Kumaran, K.; Cooper, C. Developmental origins of health and disease: A lifecourse approach to the prevention of non-communicable diseases. Healthcare 2017, 5, 14. [CrossRef] [PubMed]

8. Whitmee, S.; Haines, A.; Beyrer, C.; Boltz, F.; Capon, A.G.; de Souza Dias, B.F.; Ezeh, A.; Frumkin, H.; Gong, P.; Head, P.; et al. Safeguarding human health in the anthropocene epoch: Report of the rockefeller foundation-lancet commission on planetary health. Lancet 2015, 386, 1973-2028. [CrossRef]

9. Craig, J.M.; Prescott, S.L. Planning ahead: The mental health value of natural environments. Lancet Planet Health 2017, 1, e128-e129. [CrossRef]

10. Ruokolainen, L.; Lehtimäki, J.; Karkman, A.; Haahtela, T.; von Hertzen, L.; Fyhrquist, N. Holistic view on health: Two protective layers of biodiversity. Ann. Zool. Fenn. 2017, 54, 39-49. [CrossRef]

11. Monge, G.; Jimenez-Espejo, F.J.; Garcia-Alix, A.; Martinez-Ruiz, F.; Mattielli, N.; Finlayson, C.; Ohkouchi, N.; Sanchez, M.C.; de Castro, J.M.; Blasco, R.; et al. Earliest evidence of pollution by heavy metals in archaeological sites. Sci. Rep. 2015, 5, 14252. [CrossRef] [PubMed]

12. Waters, C.N.; Zalasiewicz, J.; Summerhayes, C.; Barnosky, A.D.; Poirier, C.; Galuszka, A.; Cearreta, A.; Edgeworth, M.; Ellis, E.C.; Ellis, M.; et al. The anthropocene is functionally and stratigraphically distinct from the holocene. Science 2016, 351, aad2622. [CrossRef] [PubMed]

13. Voosen, P. Anthropocene pinned to postwar period. Science 2016, 353, 852-853. [CrossRef] [PubMed]

14. Carey, J. Core concept: Are we in the "anthropocene"? Proc. Natl. Acad. Sci. USA 2016, 113, 3908-3909. [CrossRef] [PubMed]

15. Allen, L. Are we facing a noncommunicable disease pandemic? J. Epidemiol. Glob. Health 2017, 7, 5-9. [CrossRef] [PubMed]

16. Logan, A.C.; Katzman, M.A.; Balanza-Martinez, V. Natural environments, ancestral diets, and microbial ecology: Is there a modern "paleo-deficit disorder"? Part II. J. Physiol. Anthropol. 2015, 34, 9. [CrossRef] [PubMed]

17. Whalen, K.A.; Judd, S.; McCullough, M.L.; Flanders, W.D.; Hartman, T.J.; Bostick, R.M. Paleolithic and mediterranean diet pattern scores are inversely associated with all-cause and cause-specific mortality in adults. J. Nutr. 2017, 147, 612-620. [CrossRef] [PubMed]

18. James, P.; Seward, M.W.; James O'Malley, A.; Subramanian, S.V.; Block, J.P. Changes in the food environment over time: Examining 40 years of data in the framingham heart study. Int. J. Behav. Nutr. Phys. Act. 2017, 14, 84. [CrossRef] [PubMed]

19. Zenk, S.N.; Tarlov, E.; Powell, L.M. Weight and veterans' environments study (waves) I and II. Am. J. Health Promot. 2017. [CrossRef]

20. Wang, Y.; Wang, L.; Xue, H.; Qu, W. A review of the growth of the fast food industry in China and its potential impact on obesity. Int. J. Environ. Res. Public Health 2016, 13, 1112. [CrossRef] [PubMed]

21. Monteiro, C.A.; Moubarac, J.C.; Levy, R.B.; Canella, D.S.; Louzada, M.; Cannon, G. Household availability of ultra-processed foods and obesity in nineteen European countries. Public Health Nutr. 2017, 1-9. [CrossRef] [PubMed]

22. Martinez Steele, E.; Popkin, B.M.; Swinburn, B.; Monteiro, C.A. The share of ultra-processed foods and the overall nutritional quality of diets in the U.S.: Evidence from a nationally representative cross-sectional study. Popul. Health Metr. 2017, 15, 6. [CrossRef] [PubMed]

23. Moubarac, J.C.; Batal, M.; Louzada, M.L.; Martinez Steele, E.; Monteiro, C.A. Consumption of ultra-processed foods predicts diet quality in Canada. Appetite 2017, 108, 512-520. [CrossRef] [PubMed]

24. Stuart, H. Reducing the stigma of mental illness. Glob. Ment. Health 2016, 3, e17. [CrossRef] [PubMed]

25. Twenge, J.M.; Honeycutt, N.; Prislin, R.; Sherman, R.A. More polarized but more independent: Political party identification and ideological self-categorization among U.S. Adults, college students, and late adolescents, 1970-2015. Pers. Soc. Psychol. Bull. 2016, 42, 1364-1383. [CrossRef] [PubMed] 
26. Cosma, A.; Whitehead, R.; Neville, F.; Currie, D.; Inchley, J. Trends in bullying victimization in Scottish adolescents 1994-2014: Changing associations with mental well-being. Int. J. Public Health 2017, 62, 639-646. [CrossRef] [PubMed]

27. Rosen, C.C.; Koopman, J.; Gabriel, A.S.; Johnson, R.E. Who strikes back? A daily investigation of when and why incivility begets incivility. J. Appl. Psychol. 2016, 101, 1620-1634. [CrossRef] [PubMed]

28. Twenge, J.M. Overwhelming evidence for generation ME. Emerg. Adulthood 2013, 1, 21-26. [CrossRef]

29. Twenge, J.M.; Campbell, W.K. Birth cohort differences in the monitoring the future dataset and elsewhere: Further evidence for generation me-commentary on Trzesniewski \& Donnellan (2010). Perspect. Psychol. Sci. 2010, 5, 81-88. [PubMed]

30. Bockler, A.; Sharifi, M.; Kanske, P.; Dziobek, I.; Singer, T. Social decision making in narcissism: Reduced generosity and increased retaliation are driven by alterations in perspective-taking and anger. Personal. Individ. Differ. 2017, 104, 1-7. [CrossRef]

31. Campbell, W.K.; Bush, C.P.; Brunell, A.B.; Shelton, J. Understanding the social costs of narcissism: The case of the tragedy of the commons. Pers. Soc. Psychol. Bull. 2005, 31, 1358-1368. [CrossRef] [PubMed]

32. Blinkhorn, V.; Lyons, M.; Almond, L. Drop the bad attitude! Narcissism predicts acceptance of violent behaviour. Personal. Individ. Differ. 2016, 98, 157-161. [CrossRef]

33. Twenge, J.M.; Campbell, W.K.; Carter, N.T. Declines in trust in others and confidence in institutions among American adults and late adolescents, 1972-2012. Psychol. Sci. 2014, 25, 1914-1923. [CrossRef] [PubMed]

34. Hampton, K.M. Why is helping behavior declining in the United States but not in Canada?: Ethnic diversity, new technologies, and other explanations. City Community 2016, 15, 380-399. [CrossRef]

35. Stuckler, D. The dispossessed: A public health response to the rise of the far-right in Europe and North America. Eur. J. Public Health 2017, 27, 5-6. [CrossRef] [PubMed]

36. McKee, M. Health professionals must uphold truth and human rights. Eur. J. Public Health 2017, $27,6-7$. [CrossRef] [PubMed]

37. Baxter, A.J.; Scott, K.M.; Ferrari, A.J.; Norman, R.E.; Vos, T.; Whiteford, H.A. Challenging the Myth of an "epidemic" of common mental disorders: Trends in the global prevalence of anxiety and depression between 1990 and 2010. Depression Anxiety 2014, 31, 506-516. [CrossRef] [PubMed]

38. Cohen, S.; Janicki-Deverts, D. Who's stressed? Distributions of psychological stress in the United States in probability samples from 1983, 2006, and 2009. J. Appl. Soc. Psychol. 2012, 42, 1320-1334. [CrossRef]

39. Boak, A.; Hamilton, H.A.; Adlaf, E.M.; Henderson, J.L.; Mann, R.E. The Mental Well-Being of Ontario Students, 1991-2015; CAMH Research Document No. 43; The Centre for Addiction and Mental Health: Toronto, ON, Canada, 2016.

40. Rowlands, I.J.; Dobson, A.J.; Mishra, G.D. Physical health of young, Australian women: A comparison of two national cohorts surveyed 17 years apart. PLoS ONE 2015, 10, e0142088. [CrossRef] [PubMed]

41. Twenge, J.M. Time period and birth cohort differences in depressive symptoms in the U.S., 1982-2013. Soc. Indic. Res. 2015, 121, 437. [CrossRef]

42. Glasgow, S.; Schrecker, T. The double burden of neoliberalism? Noncommunicable disease policies and the global political economy of risk. Health Place 2016, 39, 204-211. [CrossRef] [PubMed]

43. Brijnath, B.; Antoniades, J. "I'm running my depression:" Self-management of depression in neoliberal Australia. Soc. Sci. Med. 2016, 152, 1-8. [CrossRef] [PubMed]

44. Davies, J. Political pills: Psychopharmaceuticals and neoliberalism as mutually supporting. In The Sedated Society, lst ed.; Springer International: Gewerbestrasse, Switzerland, 2017; pp. 189-225.

45. Salk, J. Research fund for human welfare. Daily Press 1966, 71, 34.

46. Stassinopoulos, A. Dr Jonas Salk's formula for the future. Courage. Love. Forgiveness. Parade Magazine, 4 Norvember 1984.

47. Davidson, K. Jonas Salk tackles the meaning of life. Los Angeles Times, 6 July 1983, Section II: 1,5.

48. Dubos, R. The human landscape. Bull. At. Sci. 1970, 26, 31-37. [CrossRef]

49. Dubos, R. Priorities debated. Moon or earth? Index Journal, 28 July 1969, p. 4.

50. Dubos, R. The genius of design. The Rest of Our Lives. In Proceedings of the International Design Conference, Aspen, CO, USA, 15-20 June 1969; pp. 57-63.

51. Corburn, J. Concepts for studying urban environmental justice. Curr. Environ. Health Rep. 2017, 4, 61-67. [CrossRef] [PubMed]

52. Smith, K. Trillion-dollar brain drain. Nature 2011, 478, 15. [CrossRef] [PubMed] 
53. Bouchery, E.E.; Harwood, H.J.; Sacks, J.J.; Simon, C.J.; Brewer, R.D. Economic costs of excessive alcohol consumption in the U.S., 2006. Am. J. Prev. Med. 2011, 41, 516-524. [CrossRef] [PubMed]

54. Hansen, R.N.; Oster, G.; Edelsberg, J.; Woody, G.E.; Sullivan, S.D. Economic costs of nonmedical use of prescription opioids. Clin. J. Pain 2011, 27, 194-202. [CrossRef] [PubMed]

55. Al-Rousan, T.; Rubenstein, L.; Sieleni, B.; Deol, H.; Wallace, R.B. Inside the nation's largest mental health institution: A prevalence study in a state prison system. BMC Public Health 2017, 17, 342. [CrossRef] [PubMed]

56. Kiss, D.; Ambeskovic, M.; Montina, T.; Metz, G.A. Stress transgenerationally programs metabolic pathways linked to altered mental health. Cell. Mol. Life Sci. 2016, 73, 4547-4557. [CrossRef] [PubMed]

57. Baams, L.; Talmage, C.A.; Russell, S.T. Economic costs of bias-based bullying. Sch. Psychol. Q. 2017. [CrossRef] [PubMed]

58. Zurbrugg, L.; Miner, K.N. Gender, sexual orientation, and workplace incivility: Who is most targeted and who is most harmed? Front. Psychol. 2016, 7, 565. [CrossRef] [PubMed]

59. Johnson, S.A. The cost of war on public health: An exploratory method for understanding the impact of conflict on public health in Sri Lanka. PLoS ONE 2017, 12, e0166674. [CrossRef] [PubMed]

60. Thomas, H.J.; Connor, J.P.; Lawrence, D.M.; Hafekost, J.M.; Zubrick, S.R.; Scott, J.G. Prevalence and correlates of bullying victimisation and perpetration in a nationally representative sample of Australian youth. Aust. N. Z. J. Psychiatry 2017. [CrossRef] [PubMed]

61. Wallace, L.N.; Menard, K.S. Friendships lost: The social consequences of violent victimization. J. Aggress. Maltreat. Trauma 2017, 26, 116-136. [CrossRef] [PubMed]

62. Czarna, A.Z.; Leifeld, P.; Smieja, M.; Dufner, M.; Salovey, P. Do narcissism and emotional intelligence win us friends? Modeling dynamics of peer popularity using inferential network analysis. Pers. Soc. Psychol. Bull. 2016, 42, 1588-1599. [CrossRef] [PubMed]

63. Goodman, G.; Gershwin, M.E.; Bercovich, D. Mars can wait: Facing the challenges of our civilization. Isr. Med. Assoc. J. 2014, 16, 744-747. [PubMed]

64. U.S. House of Science, Space, and Technology. 115th Congress (2017-2018). National Aeronautics and Space Administration Transition Authorization Act of 2017. Available online: https: / www.congress.gov/bill/ 115th-congress/senate-bill/442/text (accessed on 30 July 2017).

65. National Institutes of Health (NIH). HHS FY 2017 Budget in Brief. Available online: https://www.hhs.gov/ about/budget/fy2017/budget-in-brief/nih/index.html (accessed on 22 July 2017).

66. Hiltzik, M. Trump's Call for Human Space Exploration is Hugely Wasteful and Pointless. Available online: http:/ / www.latimes.com/business/hiltzik/la-fi-hiltzik-trump-space-20170228-story.html (accessed on 30 August 2017).

67. Vietnam War U.S. Casualties in 1969. Available online: http://www.vietnamwarcasualties.org/index.php? page $=$ directory $\& d d=1969$ (accessed on 30 July 2017).

68. World Health Organization. Mental Health Atlas 2011. Available online: http://apps.who.int/iris/ bitstream/10665/44697/1/9799241564359_eng.pdf (accessed on 12 July 2017).

69. Locke, R. All the problems of man are not going to be solved in a laboratory. Advocate Newark 1984, 164, 1B.

70. Salk, J.E. Biology in the future. Perspect. Biol. Med. 1962, 5, 423-431. [CrossRef] [PubMed]

71. Scarr, L. Dr. Salk: Book deals with man's relation, not medicine. Courier-Post 1972, 97, 61.

72. Salk, J.E. Biological basis of disease and behaviour. Perspect. Biol. Med. 1962, 5, 198-206. [CrossRef] [PubMed]

73. Dighton, R. Polio conqueror jonas salk readies new attack against disease. Prog. Index 1964, 100, 6.

74. McEwen, B.S. Brain on stress: How the social environment gets under the skin. Proc. Natl. Acad. Sci. USA 2012, 109, 17180-17185. [CrossRef] [PubMed]

75. Renz, H.; Holt, P.G.; Inouye, M.; Logan, A.C.; Prescott, S.L.; Sly, P.D. An exposome perspective: Early-life events and immune development in a changing world. J. Allergy Clin. Immunol. 2017, 140, 24-40. [CrossRef] [PubMed]

76. Franco, F.G.M.; Laurinavicius, A.G.; Lotufo, P.A.; Conceicao, R.D.; Morita, F.; Katz, M.; Wajngarten, M.; Carvalho, J.A.M.; Bosworth, H.B.; Santos, R.D. Persistent depressive symptoms are independent predictors of low-grade inflammation onset among healthy individuals. Arq. Bras. Cardiol. 2017. [CrossRef] [PubMed]

77. Wagner, E.Y.; Wagner, J.T.; Glaus, J.; Vandeleur, C.L.; Castelao, E.; Strippoli, M.P.; Vollenweider, P.; Preisig, M.; von Kanel, R. Evidence for chronic low-grade systemic inflammation in individuals with agoraphobia from a population-based prospective study. PLoS ONE 2015, 10, e0123757. [CrossRef] [PubMed] 
78. Messay, B.; Lim, A.; Marsland, A.L. Current understanding of the bi-directional relationship of major depression with inflammation. Biol. Mood Anxiety Disord. 2012, 2, 4. [CrossRef] [PubMed]

79. Ligthart, S.; Marzi, C.; Aslibekyan, S.; Mendelson, M.M.; Conneely, K.N.; Tanaka, T.; Colicino, E.; Waite, L.L.; Joehanes, R.; Guan, W.; et al. DNA methylation signatures of chronic low-grade inflammation are associated with complex diseases. Genome Biol. 2016, 17, 255. [CrossRef] [PubMed]

80. Bonaccio, M.; Di Castelnuovo, A.; Pounis, G.; De Curtis, A.; Costanzo, S.; Persichillo, M.; Cerletti, C.; Donati, M.B.; de Gaetano, G.; Iacoviello, L.; et al. A score of low-grade inflammation and risk of mortality: Prospective findings from the moli-sani study. Haematologica 2016, 101, 1434-1441. [CrossRef] [PubMed]

81. Chehoud, C.; Rafail, S.; Tyldsley, A.S.; Seykora, J.T.; Lambris, J.D.; Grice, E.A. Complement modulates the cutaneous microbiome and inflammatory milieu. Proc. Natl. Acad. Sci. USA 2013, 110, 15061-15066. [CrossRef] [PubMed]

82. Zeng, M.Y.; Inohara, N.; Nunez, G. Mechanisms of inflammation-driven bacterial dysbiosis in the gut. Mucosal Immunol. 2017, 10, 18-26. [CrossRef] [PubMed]

83. Sender, R.; Fuchs, S.; Milo, R. Revised estimates for the number of human and bacteria cells in the body. PLoS Biol. 2016, 14, e1002533. [CrossRef] [PubMed]

84. Human Microbiome Project Consortium. A framework for human microbiome research. Nature 2012, 486, 215-221.

85. Prescott, S.L. History of medicine: Origin of the term microbiome and why it matters. Hum. Microbiome J. 2017, 4, 24-25. [CrossRef]

86. Gupta, V.K.; Paul, S.; Dutta, C. Geography, ethnicity or subsistence-specific variations in human microbiome composition and diversity. Front. Microbiol. 2017, 8, 1162. [CrossRef] [PubMed]

87. Segata, N. Gut microbiome: Westernization and the disappearance of intestinal diversity. Curr. Biol. 2015, 25, R611-R613. [CrossRef] [PubMed]

88. Sonnenburg, E.D.; Smits, S.A.; Tikhonov, M.; Higginbottom, S.K.; Wingreen, N.S.; Sonnenburg, J.L. Diet-induced extinctions in the gut microbiota compound over generations. Nature 2016, 529, 212-215. [CrossRef] [PubMed]

89. Petersen, C.; Round, J.L. Defining dysbiosis and its influence on host immunity and disease. Cell. Microbiol. 2014, 16, 1024-1033. [CrossRef] [PubMed]

90. Zhang, Y.J.; Li, S.; Gan, R.Y.; Zhou, T.; Xu, D.P.; Li, H.B. Impacts of gut bacteria on human health and diseases. Int. J. Mol. Sci. 2015, 16, 7493-7519. [CrossRef] [PubMed]

91. Logan, A.C. Dysbiotic drift: Mental health, environmental grey space, and microbiota. J. Physiol. Anthropol. 2015, 34, 23. [CrossRef] [PubMed]

92. Corburn, J. Confronting the challenges in reconnecting urban planning and public health. Am. J. Public Health 2004, 94, 541-546. [CrossRef] [PubMed]

93. Cheon, B.K.; Hong, Y.Y. Mere experience of low subjective socioeconomic status stimulates appetite and food intake. Proc. Natl. Acad. Sci. USA 2017, 114, 72-77. [CrossRef] [PubMed]

94. Bratanova, B.; Loughnan, S.; Klein, O.; Claassen, A.; Wood, R. Poverty, inequality, and increased consumption of high calorie food: Experimental evidence for a causal link. Appetite 2016, 100, 162-171. [CrossRef] [PubMed]

95. Cardel, M.I.; Johnson, S.L.; Beck, J.; Dhurandhar, E.; Keita, A.D.; Tomczik, A.C.; Pavela, G.; Huo, T.; Janicke, D.M.; Muller, K.; et al. The effects of experimentally manipulated social status on acute eating behavior: A randomized, crossover pilot study. Physiol. Behav. 2016, 162, 93-101. [CrossRef] [PubMed]

96. Laxer, R.E.; Janssen, I. The proportion of excessive fast-food consumption attributable to the neighbourhood food environment among youth living within $1 \mathrm{~km}$ of their school. Appl. Physiol. Nutr. Metab. 2014, 39, 480-486. [CrossRef] [PubMed]

97. Lucan, S.C.; Maroko, A.R.; Sanon, O.C.; Schechter, C.B. Unhealthful food-and-beverage advertising in subway stations: Targeted marketing, vulnerable groups, dietary intake, and poor health. J. Urban Health Bull. N. Y. Acad. Med. 2017, 94, 220-232. [CrossRef] [PubMed]

98. Arredondo, E.; Castaneda, D.; Elder, J.P.; Slymen, D.; Dozier, D. Brand name logo recognition of fast food and healthy food among children. J. Community Health 2009, 34, 73-78. [CrossRef] [PubMed]

99. Zenk, S.N.; Powell, L.M.; Rimkus, L.; Isgor, Z.; Barker, D.C.; Ohri-Vachaspati, P.; Chaloupka, F. Relative and absolute availability of healthier food and beverage alternatives across communities in the United States. Am. J. Public Health 2014, 104, 2170-2178. [CrossRef] [PubMed] 
100. Rimkus, L.; Isgor, Z.; Ohri-Vachaspati, P.; Zenk, S.N.; Powell, L.M.; Barker, D.C.; Chaloupka, F.J. Disparities in the availability and price of low-fat and higher-fat milk in U.S. food stores by community characteristics. J. Acad. Nutr. Diet. 2015, 115, 1975-1985. [CrossRef] [PubMed]

101. Cameron, A.J.; Thornton, L.E.; McNaughton, S.A.; Crawford, D. Variation in supermarket exposure to energy-dense snack foods by socio-economic position. Public Health Nutr. 2013, 16, 1178-1185. [CrossRef] [PubMed]

102. Rose, D.; Hutchinson, P.L.; Bodor, J.N.; Swalm, C.M.; Farley, T.A.; Cohen, D.A.; Rice, J.C. Neighborhood food environments and body mass index: The importance of in-store contents. Am. J. Prev. Med. 2009, 37, 214-219. [CrossRef] [PubMed]

103. Farley, T.A.; Rice, J.; Bodor, J.N.; Cohen, D.A.; Bluthenthal, R.N.; Rose, D. Measuring the food environment: Shelf space of fruits, vegetables, and snack foods in stores. J. Urban Health Bull. N. Y. Acad. Med. 2009, 86, 672-682. [CrossRef] [PubMed]

104. Burgoine, T.; Forouhi, N.G.; Griffin, S.J.; Brage, S.; Wareham, N.J.; Monsivais, P. Does neighborhood fast-food outlet exposure amplify inequalities in diet and obesity? A cross-sectional study. Am. J. Clin. Nutr. 2016, 103, 1540-1547. [CrossRef] [PubMed]

105. Kahr, M.K.; Suter, M.A.; Ballas, J.; Ramin, S.M.; Monga, M.; Lee, W.; Hu, M.; Shope, C.D.; Chesnokova, A.; Krannich, L.; et al. Geospatial analysis of food environment demonstrates associations with gestational diabetes. Am. J. Obstet. Gynecol. 2016, 214, 110.e1-110.e9. [CrossRef] [PubMed]

106. Turi, K.N.; Grigsby-Toussaint, D.S. Spatial spillover and the socio-ecological determinants of diabetes-related mortality across us counties. Appl. Geogr. 2017, 85, 62-72. [CrossRef]

107. Moodie, R.; Stuckler, D.; Monteiro, C.; Sheron, N.; Neal, B.; Thamarangsi, T.; Lincoln, P.; Casswell, S.; Lancet, N.C.D.A.G. Profits and pandemics: Prevention of harmful effects of tobacco, alcohol, and ultra-processed food and drink industries. Lancet 2013, 381, 670-679. [CrossRef]

108. Albrecht, G. Ecopsychology in the symbiocene. Ecopsychology 2014, 6, 58-59. [CrossRef]

109. Manzoni, C.; Kia, D.A.; Vandrovcova, J.; Hardy, J.; Wood, N.W.; Lewis, P.A.; Ferrari, R. Genome, transcriptome and proteome: The rise of omics data and their integration in biomedical sciences. Brief. Bioinform. 2016. [CrossRef]

110. Ceballos, G.; Ehrlich, P.R.; Dirzo, R. Biological annihilation via the ongoing sixth mass extinction signaled by vertebrate population losses and declines. Proc. Natl. Acad. Sci. USA 2017, 114, E6089-E6096. [CrossRef] [PubMed]

111. Weintraub, P. The new epoch: Jonas Salk. In The Omni Interviews; Weintraub, P., Ed.; Ticknor and fields: Boston, MA, USA, 1984; pp. 94-115.

112. Salk, J. The Survival of the Wisest; Harper and Row: San Francisco, CA, USA, 1973.

113. Huff, C. The growth of holistic health. Philadelphia Inquirer, 3 November 1977, p. 52.

114. Newsmakers: The challenge of science, Jonas Salk speaks. Philadelphia Inquirer, 11 October 1992, p. 3.

115. Albrecht, G.A. Exiting the anthropocene and entering the symbiocene. Minding Nat. 2016, 9, 12-16.

116. Christian, N.; Herre, E.A.; Mejia, L.C.; Clay, K. Exposure to the leaf litter microbiome of healthy adults protects seedlings from pathogen damage. Proc. Biol. Sci. 2017, 284, 20170641. [CrossRef] [PubMed]

117. Soga, M.; Gaston, K.J.; Yamaura, Y.; Kurisu, K.; Hanaki, K. Both direct and vicarious experiences of nature affect children's willingness to conserve biodiversity. Int. J. Environ. Res. Public Health 2016, 13, 529. [CrossRef] [PubMed]

118. Watt, K.; Abbott, P.; Reath, J. Developing cultural competence in general practitioners: An integrative review of the literature. BMC Fam. Pract. 2016, 17, 158. [CrossRef] [PubMed]

119. McEwen, B.S. Integrative medicine: Breaking down silos of knowledge and practice an epigenetic approach. Metab. Clin. Exp. 2017, 69S, S21-S29. [CrossRef] [PubMed]

120. Gray, B. How should we respond to non-dominant healing practices, the example of homeopathy. J. Bioeth. Inq. 2017, 14, 87-96. [CrossRef] [PubMed]

121. Cloud, R. No Funds for Homeless Vets. Program Eliminated in King. Available online: http://www. waupacanow.com/2017/07/17/no-funds-for-homeless-vets/ (accessed on 30 July 2017).

122. Halpern, L.W. Analysis finds about 20 veterans died daily from suicide between 2001 and 2014. Am. J. Nurs. 2016, 116, 17. [CrossRef] [PubMed]

123. McKee, M.; Stuckler, D.; Zeegers Paget, D.; Dorner, T. The Vienna declaration on public health. Eur. J. Public Health 2016, 26, 897-898. [CrossRef] [PubMed] 
124. Shelton, D.L. Problems in environmental protection and human rights: A human right to the environment. GL Law Scholarly Commons 2011. [CrossRef]

125. United Nations General Assembly. Convention on the Rights of the Child; United Nations Treaty Series; United Nations General Assembly: New York, NY, USA, 1989.

126. Craig, J.M.; Logan, A.C.; Prescott, S.L. Natural environments, nature relatedness and the ecological theater: Connecting satellites and sequencing to Shinrin-Yoku. J. Physiol. Anthropol. 2016, 35, 1. [CrossRef] [PubMed]

127. Metz, A.L. Back to nature: The relationship between nature relatedness on empathy and narcissism in the millennial generation. Vistas Online 2017, 11, 1-14.

128. Martyn, P.; Brymer, E. The relationship between nature relatedness and anxiety. J. Health Psychol. 2016, 21, 1436-1445. [CrossRef] [PubMed]

129. Yang, Y.; Geng, L.; Xiang, P.; Zhang, J.; Zhu, L. Nature connectedness: It's concept, measurement, function and intervention. Adv. Psychol. Sci. 2017, 25, 1360-1374.

130. Asah, S.T.; Bengston, D.N.; Westphal, L.M.; Gowan, C.H. Mechanisms of children's exposure to nature: Predicting adulthood environmental citizenship and commitment to nature-based activities. Environ. Behav. 2017. [CrossRef]

131. Allemand, M.; Steiger, A.E.; Fend, H.A. Empathy development in adolescence predicts social competencies in adulthood. J. Pers. 2015, 83, 229-241. [CrossRef] [PubMed]

132. Sanchez-Alvarez, N.; Extremera, N.; Fernandez-Berrocal, P. The relation between emotional intelligence and subjective well-being: A meta-analytic investigation. J. Posit. Psychol. 2016, 11, 276-285. [CrossRef]

133. Schutte, N.S.; Malouff, J.M.; Thorsteinsson, E.B.; Bhullar, N.; Rooke, S.E. A meta-analytic investigation of the relationship between emotional intelligence and health. Pers. Indiv. Differ. 2007, 42, 921-933. [CrossRef]

134. Zeidner, M.; Matthews, G.; Roberts, R.D. The emotional intelligence, health, and well-being nexus: What have we learned and what have we missed? Appl. Psychol. Health Well Being 2012, 4, 1-30. [CrossRef] [PubMed]

135. Extremera, N.; Rey, L. Ability emotional intelligence and life satisfaction: Positive and negative affect as mediators. Person.l Indiv. Diff. 2016, 102, 98-101. [CrossRef]

136. Abdollahi, A.; Abu Talib, M.; Motalebi, S.A. Emotional intelligence and depressive symptoms as predictors of happiness among adolescents. Iran J. Psychiatry Behav. Sci. 2015, 9, e2268. [CrossRef] [PubMed]

137. Killgore, W.D.; Kahn-Greene, E.T.; Lipizzi, E.L.; Newman, R.A.; Kamimori, G.H.; Balkin, T.J. Sleep deprivation reduces perceived emotional intelligence and constructive thinking skills. Sleep Med. 2008, 9, 517-526. [CrossRef] [PubMed]

138. Mavroveli, S.; Sanchez-Ruiz, M.J. Trait emotional intelligence influences on academic achievement and school behaviour. Br. J. Educ. Psychol. 2011, 81, 112-134. [CrossRef] [PubMed]

139. Costa, A.; Faria, L. The impact of emotional intelligence on academic achievement: A longitudinal study in Portuguese secondary school. Learn Individ. Differ. 2015, 37, 38-47. [CrossRef]

140. Curci, A.; Lanciano, T.; Soleti, E. Emotions in the classroom: The role of teachers' emotional intelligence ability in predicting students' achievement. Am. J. Psychol. 2014, 127, 431-445. [CrossRef] [PubMed]

141. Aminabadi, N.A.; Pourkazemi, M.; Babapour, J.; Oskouei, S.G. The impact of maternal emotional intelligence and parenting style on child anxiety and behavior in the dental setting. Med. Oral Patol. Oral 2012, 17, E1089-E1095. [CrossRef]

142. Ulutas, I.; Omeroglu, E. Maternal attitudes, emotional intelligence and home environment and their relations with emotional intelligence of sixth years old children, emotional intelligence. In New Perspectives and Applications; di fabio, A., Ed.; Intech: Rijeka, Croatia, 2012.

143. Slaski, M.; Cartwright, S. Emotional intelligence training and its implications for stress, health and performance. Stress Health 2003, 19, 233-239. [CrossRef]

144. Nyklicek, I.; Schalken, P.; Meertens, S. The role of emotional intelligence in symptom reduction after psychotherapy in a heterogeneous psychiatric sample. Compr. Psychiat. 2015, 57, 65-72. [CrossRef] [PubMed]

145. Castillo, R.; Salguero, J.M.; Fernandez-Berrocal, P.; Balluerka, N. Effects of an emotional intelligence intervention on aggression and empathy among adolescents. J. Adolescence 2013, 36, 883-892. [CrossRef] [PubMed]

146. Bonaccio, M.; Di Castelnuovo, A.; De Curtis, A.; Costanzo, S.; Bracone, F.; Persichillo, M.; Donati, M.B.; de Gaetano, G.; Iacoviello, L.; Moli-sani Project, I. Nut consumption is inversely associated with both cancer 
and total mortality in a mediterranean population: Prospective results from the Moli-Sani study. Br. J. Nutr. 2015, 114, 804-811. [CrossRef] [PubMed]

147. Dubos, R. Symbiosis between the earth and humankind. Science 1976, 193, 459-462. [CrossRef] [PubMed]

148. Azeredo, C.M.; Santos, I.S.; Barros, A.J.D.; Barros, F.C.; Matijasevich, A. Maternal depression and bullying victimization among adolescents: Results from the 2004 pelotas cohort study. Depress Anxiety 2017. [CrossRef] [PubMed]

149. Horton, R.; Beaglehole, R.; Bonita, R.; Raeburn, J.; McKee, M.; Wall, S. From public to planetary health: A manifesto. Lancet 2014, 383, 847. [CrossRef]

150. Wang, Y.; Jing, X.; Lv, K.; Wu, B.; Bai, Y.; Luo, Y.; Chen, S.; Li, Y. During the long way to mars: Effects of 520 days of confinement (mars500) on the assessment of affective stimuli and stage alteration in mood and plasma hormone levels. PLoS ONE 2014, 9, e87087. [CrossRef] [PubMed]

151. Schuster, H.; Peck, S.L. Mars ain't the kind of place to raise your kid: Ethical implications of pregnancy on missions to colonize other planets. Life Sci. Soc. Policy 2016, 12, 10. [CrossRef] [PubMed]

152. Smollar, D. 30 years after 1st vaccine, dr jonas salk still strives to eradicate polio. Los Angeles Times, 7 April 1985, Part II, p. 9.

153. Heuck, D. Institute a blueprint for a new way of thinking. Pittsburgh-Post Gazette, 28 November 1994, pp. a1-a6. 154. Houseman, M.P. Salk believes institute most important creation. Ottawa J. 1980, 12, 32.

(c) 2017 by the authors. Licensee MDPI, Basel, Switzerland. This article is an open access article distributed under the terms and conditions of the Creative Commons Attribution (CC BY) license (http:// creativecommons.org/licenses/by/4.0/). 